\title{
Tantangan Budaya dalam Mewujudkan Kesetaraan Gender di India dan Solusinya
}

\author{
Agneta Kristalia Tedjo, Mohammad Daffa Ramadhan, \\ Muhammad Daffa Dirgantara, dan Raden Arief \\ Meivio Bahari \\ Universitas Padjajaran
}

\begin{abstract}
Abstrak
Keadaan dimana laki-laki dan perempuan seharusnya memiliki hak yang setara memang harus diwujudkan dimanapun, termasuk di negara India. Oleh karena itu, artikel ini akan membahas mengenai keadaaan kesetaraan gender di India dan keadaan perempuan di sana. India dinobatkan oleh Tom Reuters Foundation sebagai negara ke-4 paling berbahaya di dunia. Salah satu faktor penyebabnya adalah tradisi budaya yang telah mengakar selama turun temurun. Maka dari itu, penting untuk membahas lebih lanjut mengenai kesetaraan gender di India. Artikel kemudian akan membahas solusi dari budaya yang merugikan perempuan di India. Pendidikan menjadi salah satu aspek yang digunakan untuk mengurangi bentuk diskriminasi yang ada di India, maka dilakukan upaya untuk mengatasi tingkat buta huruf yang sangat tinggi dan juga ketimpangan pendidikan untuk perempuan. Artikel juga membahas pentingnya peran pihak luar untuk terlibat dalam perwujudan kesetaraan gender di India; berbagai konvensi guna mencapai kesetaraan gender dan pemenuhan hak asasi manusia, khususnya bagi perempuan; serta, pentingnya peran pemerintah India untuk menciptakan lingkungan yang ramah terhadap perempuan.
\end{abstract}

Kata kunci: Kesetaraan Gender; India; Budaya; Pendidikan; Perempuan

A condition where women and men should have equal position on every aspect of life is indeed should be realized in every part of the world, including India. This article will discuss an overview of the condition of gender equality in India. In- dia was named by the Tom Reuters Foundation as the 4th most dangerous coun- try in the world. One of the many factors why this happen is because of the exis- tence of cultural traditions that have deeply rooted for generations. Therefore, it is necessary to discuss further the importance of gender equality in India. The authors will try to explain the solution to the culture that bring harm to women in India. Education is one aspect that is used to reduce any discrimination that existed in India. The main goal of India in education is to overcome high illiter- acy rate and also educational inequality for women. It will also be discussed, what are the roles of outsiders involved in the realization of gender equality in India. How conventions also play a role in helping India achieve gender equality and fulfilment of human rights, especially for women. As well as the role of the Indian government to create a good environment for women.

Keywords: Gender Equality; India; Culture; Education; Women 


\section{Pendahuluan}

Saat ini istilah kesetaraan gender bukan lagi menjadi hal yang asing di dengar. Kesetaraan gender bisa diartikan sebagai kesamaan kondisi laki-laki dan perempuan untuk memperoleh kesempatan, hak, maupun kewajiban sebagai manusia dalam segala aspek kehidupan serta hak untuk menikmati segala hasil pembangunan. Sederhananya, kesetaraan gender merupakan keadaan dimana perempuan dan laki-laki mendapatkan hak yang sama di segala bidang tanpa mengalami diskriminasi. Kesetaraan gender harus diterapkan di seluruh dunia agar tidak terjadi ketimpangan atau diskriminasi terhadap salah satu gender, tidak terkecuali di negara India. Berdasarkan survei yang dilakukan oleh Bank Dunia yang dilansir dari (Alinea.id 2019) hanya ada enam negara yang berhasil memiliki kesetaraan gender secara sempurna yaitu Belgia, Denmark, Prancis, Latvia, Luksemburg, dan Swedia. Disini dapat disimpulkan bahwa India belum mampu mencapai tingkat kesetaraan gender. Tom Reuters Foundation juga menempatkan India pada peringkat ke-4 sebagai negara paling berbahaya bagi perempuan. Dilansir dari BBC (2018) hal tersebut diperoleh dengan indikator layanan kesehatan, diskriminasi, tradisi budaya, kekerasan seksual dan non-seksual, dan penjualan manusia. Melihat keadaan tersebut, dapat disimpulkan betapa buruknya keadaan untuk hidup bagi perempuan di India dengan tingkat kesetaraan gender di India masih jauh dari kata tercapai. Kurangnya tingkat kesetaraan gender di India dapat disebabkan oleh beberapa faktor tetapi faktor utama yang paling kuat ialah tradisi budaya yang sudah mengakar di India itu sendiri.

Hal ini pun ditegaskan oleh Syed seorang ahli dari India, pada bukunya yang berjudul "Ein Unglück ist die Tochter" (Sialnya Anak Perempuan). Bahwa sejak dulu perempuan di India dilihat sebagai milik kaum pria. Perempuan dianggap tidak bijaksana dan hanya pria yang dianggap bijaksana. Hal ini bahkan masih terlihat sampai sekarang di India. Perempuan tidak memiliki hak untuk membangun identitasnya sendiri. Mereka hanya dilihat sebagai istri dari seorang pria atau sebagai tempat produksi anak (Apriani 2015). Adanya sistem kasta dalam struktur sosial masyarakat India juga semakin menyulitkan bagi perempuan. Adanya pembagian kelas-kelas di India tidak hanya membedakan status sosial, penghasilan, dan pekerjaan kepada kelompok tertentu tetapi juga memberikan kesempatan bagi kasta yang lebih tinggi untuk menekan kasta yang lebih rendah. Dapat dilihat bahwa faktor tradisi budaya menjadi kendala utama dalam tercapainya kesetaraan gender di India. Banyak dari tradisi-tradisi tersebut yang sangat merugikan bagi kaum perempuan di India. Kaum perempuan sangat didiskriminasi dan tidak mempunyai hak untuk setara dengan laki-laki. Maka dari itu, sudah 
seharusnya tradisi budaya yang merugikan ini harus dihilangkan. Tetapi, akan sangat sulit untuk merubah pemikiran orang tua atau orang dewasa yang mana pemikirannya sudah terbentuk oleh tradisi dan budaya. Tetapi hal ini bukan tidak mungkin terjadi bagi generasi muda atau remaja dimana pemikiran mereka masih bisa dibentuk terutama dengan pengaruh lingkungan sekitarnya. Untuk itulah peran pendidikan khususnya tentang kesetaraan gender terutama bagi para remaja sangat dibutuhkan. Dengan menumbuhkan pemikiran baru tentang pentingnya kesetaraan gender bagi semua pihak terutama perempuan maka hal ini nantinya akan berdampak pada tingkat pencapaian kesetaraan gender di India (Apriani 2015).

Dari beberapa uraian masalah di atas, maka yang akan menjadi pertanyaan dari artikel ini adalah bagaimana menghadapi tantangan budaya di India agar dapat terwujud kesetaraan gender. Pertanyaan ini nantinya bisa dijawab setelah adanya penjelasan tentang masalah pendidikan yang ada di India itu sendiri. Bagaimana penjelasan yang lebih mendalam tentang kesetaraan gender di India dan sejauh mana peran pihak-pihak yang terlibat untuk mewujudkan kesetaraan gender di India melalui pendidikan untuk remaja itu sendiri. Lalu, akan dijelaskan hambatan dan tantangan untuk mencapai kesetaraan gender dan mengapa hal itu bisa terjadi, serta bagaimana kondisi dan gambaran kesetaraan gender di India itu sendiri. Dijelaskan pula contoh-contoh kasus tentang ketidaksetaraan gender yang terjadi dan bagaimana konvensi yang diakukan oleh Convention on Elimination of All Forms of Discrimination Againts Women (CEDAW) dapat membantu India untuk mewujudkan kesetaraan gender bagi semua pihak.

\section{Kesetaraan Gender dan Contoh Kasus}

Gender dapat diartikan sebagai sebuah peran ataupun tugas antara kedudukan laki-laki dengan perempuan yang telah ditetapkan oleh masyarakat ataupun lingkungan sendiri berdasarkan sifat dari laki-laki dan perempuan dengan tetap memperhatikan kepantasan yang mengikuti sesuai norma-norma, kepercayaan, adat istiadat, serta kebiasaan masyarakatnya. Seperti laki-laki yang mempunyai ciri khas yaitu sebagai pemimpin dan kuat, berarti mempunyai tugas yang cocok seperti ciri khasnya tersebut (Komisi Perlindungan Anak Indonesia 2017). Dalam sosialisasinya, gender dapat didefinisikan sebagai suatu proses yang dapat membantu tiap individu untuk belajar dalam penyesuaian dirinya. Bagaimana individu tersebut bertindak serta berpikir agar dapat berperan dan juga berfungsi baik sesuai dengan tugas dan kaidahnya masingmasing bagi lingkungan masyaraakatnya. Gender juga dibentuk oleh masyarakat yang perilakunya tertanam melalui proses sosialisasi. 
Seperti yang telah dibahas sebelumnya, terdapat penafsiran yang berbeda dalam hal kebudayaan yang menjadi seperangkat tuntutan sosial tentang kepantasan dalam berperilaku, mendapatkan hak-hak, serta keadilan pada individu, baik perempuan dan laki-laki. Misalnya, hampir dari seluruh kelompok masyarakat bergantung kepada perempuan dalam tanggung jawab perawatan pada anak, sedangkan tugas-tugas yang lebih keras seperti hal kemiliteran diberikan pada laki-laki. Sama halnya dengan pembahasan yang berkonteks dengan ras, etnik, dan kelas gender merupakan suatu kategori sosial yang sangat menentukan jalan hidupnya tiap tiap individu serta partisipasinya dalam berkehidupan masyarakat dan ekonomi. Dari teori yang telah didapat, dikatakan bahwa tidak semua masyarakat itu terkena atau mengalami bentuk diskriminasi melainkan semua masyarakat mengalami diskriminasi berdasarkan gender dalam bentuk kesenjangan dan perbedaan dalam tingkatannya yang berbedabeda. Kadang keadilan seperti inilah yang menuai banyak perdebatan hingga saat ini.

Disini, pengertian kesetaraan gender atau biasa disebut gender equality merujuk pada suatu keadaan yang setara antara laki-laki dengan perempuan dalam pemenuhan hak dan kewajibannya. Seperti yang kita ketahui bahwa diskriminasi kesetaraan gender masih sering kali terjadi di dalam aspek kehidupan di dunia. Nilai dari sifat dan tingkatan diskriminasi sangatlah bervariasi di setiap wilayah di dunia, namun seringkali yang menjadi "korban" dalam kasus kesetaraan gender adalah perempuan. Saat ini, banyak perempuan tidak setuju dengan sistem kesetaraan gender yang berlaku ataupun pandangan masyarakat yang menganggap bahwa perempuan adalah kaum yang lemah. Banyak perempuan tidak menerima pernyataan tersebut karena bagi perempuan pandangan itu sangat menimbulkan konteks ofensif. Tidak seharusnya perempuan mendapatkan stigma buruk tersebut. Bentuk rasa tidak terima para perempuan kemudian di buktikan dengan aksi yang dilakukan oleh jutaan perempuan di India. Mereka melakukan sebuah aksi di sepanjang jalan raya di hari pertama tahun 2019 serta mengirim pesan kuat mengenai kesetaraan gender. Unjuk rasa dari jutaan perempuan ini, yang berlangsung selama 15 menit tersebut, dipicu oleh pertikaian mengenai larangan akses perempuan ke kuil Sabarimala yang terkenal di Kerala. Kuil Hindu secara historis tertutup bagi perempuan usia menstruasi. Namun, pada akhirnya pengadilan tertinggi India membatalkan larangan tersebut (Wirawan 2019).

Saat ini juga mulai muncul berbagai macam permasalahan serta kasus terhadap perempuan. Mulai dari perempuan yang direndahkan hingga kekerasan terhadap perempuan. Kesetaraan gender kemudian menjadi 
salah satu hak asasi manusia yang harus ditegakkan. Hak untuk hidup secara dihargai, bebas, dan dapat dihormati untuk setiap orang. Sehingga, sebagai manusia tidak lagi ada rasa takut dan bisa bebas untuk menentukan pilihan hidup. Hal ini tidak hanya diperuntukan bagi laki-laki saja tetapi perempuan juga mempunyai hak yang sama pada hakikatnya sendiri. Di zaman sekarang, sosok perempuan yang memiliki segudang prestasidan bisa menyeimbangkan karirnya dengan keluarga sangat sulit ditemukan. Seperti yang kita ketahui bahwa masyarakat sekarang mempunyai stigma yang berbeda untuk melihat perempuan dan itulah yang seringkali membuat perempuan takut untuk mengejar citacitanya dikarenakan tuntutan masyarakat bahwa peran perempuan hanyalah sebagai seorang ibu rumah tangga. Banyak sekali data-data yang menunjukkan bahwa di masa sekarang ini secara konsisten perempuan berada di posisi yang sangat merugikan dibanding dengan laki-laki. Hal ini dapat dilihat dan ditemukan dalam beberapa isu-isu utama dari kesenjangan gender di beberapa sektor.

Pertama, sistem pola pernikahan yang merugikan sisi perempuan. Saat ini, pernikahan dini bisa dibilang suatu hal yang lazim di Indonesia. Laporan Perserikatan Bangsa-Bangsa 2004 telah memperkirakan bahwa 13\% dari perempuan di Indonesia telah menikah di umur 15-19 tahun (Komisi Perlindungan Anak Indonesia 2017). Meskipun dalam Islam laki-laki diperbolehkan memperistri lebih dari satu orang tetapi dalam UUD perkawinan tahun 1974 telah mengatur dan menyertakan persyaratan untuk memiliki lebih dari satu orang istri. Izin tersebut akan diberikan jika suami dapat memberi bukti bahwa istri pertamanya sudah tidak dapat melaksanakan tugas dan tanggung jawabnya sebagai istri. Pegawai Negeri Sipil (PNS) Indonesia juga telah melakukan pelarangan untuk praktek poligami. Faktanya hukum perkawinan di Indonesia seperti menganggap pria sebagai kepala rumah tangga dan seseorang yang mencari nafkah untuk keluarga. Lalu tugas-tugas untuk mengurus serta membesarkan anak dan hal hal rumah tangga akan dilakukan oleh perempuan. Hal inilah yang kemudian masih banyak merugikan pihak perempuan dikarenakan jika menikah dengan perempuan dibawah umur maka dikhawatirkan jika perempuan tersebut masih belum siap untuk melaksanakan kewajiban tersebut (Wuryasti 2016).

Pernikahan usia dini juga rentan melibatkan perempuan miskin serta meningkatkan angka kemiskinan. Hal tersebutyang pada akhirnya juga mengakibatkan apa yang perempuan kerjakan hanya terbatas dalam bidang rumah tangga saja. Sehingga, saat perempuan bekerja dalam sektor informal atau ketenagakerjaan seperti pekerjaan lelaki, maka perempuan tersebut dianggap tidak terhitung atas sumbangan ataupun 
partisipasi kerjanya. Contoh kasus dapat dilihat melalui pernikahan "Andini-Arling, Polewali Mandar" yaitu sepasang remaja dari Kabupaten Polewali Mandar, Sulawesi Barat yang mengejutkan berbagai media dikarenakan Andini yang masih berusia 15 tahun menikah dengan Arling yang berumur 16 tahun. Mereka berdua masih duduk di bangku SMA dimana seharusnya mereka berdua masih bisa menikmati masa muda nya bersama teman sebayanya tetapi harus dibebankan dengan tanggung jawab sebagai kepala dan ibu rumah tangga (Kania 2017).

Kedua, kesenjangan perempuan dalam dunia pekerjaan. Terdapat pembagian jenis kelamin terhadap angkatan kerja. Praktik penerimaan dan promosi karyawan yang bersifat diskriminatif atas sebuah dasar gender. Hal-hal tersebut membuat perempuan hanya terkonsentrasi di sejumlah kecil sektor perekonomian. Ketiga, terdapat kekerasan fisik. Indonesia telah menetetapkan undang-undang untuk melindungi setiap perempuan dari terjadinya kekerasan fisik. Namun, banyak bukti yang memperlihatkan bahwa kekerasan terhadap perempuan merupakan hal yang masih umum terjacdi di Indonesia. Sesuai dengan survei demografi dan kesehatan di tahun 2003, hampir dari 25\% perempuan yang pernah menikah setuju dengan anggapan bahwa suami dibenarkan dalam melakukan kekerasan fisik. Kekerasan fisik di dalam rumah tangga memiliki berbagai alasan seperti: berbeda pendapat, mengabaikan anak, ataupun karena istri pergi tanpa sepengetahuan sang suami (Komisi Perlindungan Anak Indonesia 2017).

Selain itu, perdagangan perempuan atau prostitusi juga bisa menjadi ancaman serius bagi perempuan Indonesia. Terutama bagi mereka yang miskin dan memiliki pendidikan yang rendah. Contoh kasusnya seperti yang baru beberapa bulan ini terjadi yaitu seorang ibu rumah tangga di Depok yang mengalami suatu kejadian tidak mengenakan yaitu kekerasan fisik terhadapnya sehingga harus melapor ke polisi dengan menggunakan mobil bak terbuka (Purnama 2019). Dari situlah kita bisa sadar akan kerasnya kehidupan yang perempuan jalani di zaman sekarang. Perhatian kemudian perlu diberikan kepada perempuan seperti memberikan akses yang setara dalam pendidikan, kesehatan, pekerjaan yang layak, serta partisipasi perempuan dalam pengambilan keputusan politik dan ekonomi. Sebagaimana telah dijelaskan sebelumnya hal tersebut juga sedang terjadi di India karena banyak perempuan di India yang suaranya ditutup karena pemerintah dan masyarakat menganggap bahwa perempuan tidak perlu ikut campur dengan urusan-urusan seperti itu. 


\section{India dan Pendidikan sebagai Solusi}

India merupakan negara yang termasuk pada golongan negara-negara terluas di dunia. Luas India sekitar $3.287 .263 \mathrm{~km}^{2}$ dan tingkat kepadatan penduduk terluas di bawah Tiongkok. Sekitar 83\% mayoritas penduduk yang tinggal di India memeluk kepercayaan Hindu, sekitar 12\% memeluk agama mayoritas kedua di India yakni Islam, dan selebihnya Kristen, Siktis, dan lainnya. India sangat bertumpu pada sektor peternakan dan pertanian dalam menaikan tingkat ekonomi negaranya. Juga industri perfilman India tergolong besar di Asia dan dapat menjadi media untuk mengembangkan budaya lokal, serta mempromosikan budaya kepada dunia. India adalah negara yang berada di kawasan Asia Selatan yang memiliki keberagaman dan kemewahan dalam aspek kebudayaan di dunia dan hampir menyaingi Tiongkok dalam aspek kesusastraan, arsitektur, dan seni. Namun, dengan semua keberagaman dan kekayaan India dalam aspek budaya masih tidak banyak membantu India pada sektor perekonominya. Kesenjangan sosial masih menjadi permasalahan yang sangat mencolok pada aspek ekonomi, pendidikan, dan kesehatan. Hal tersebut dikarenakan selama 150 tahun India menjadi daerah jajahan Inggris dan baru memerdekakan dirinya pada tahun 1947 (Tanaka 2018).

Pendidikan merupakan salah satu tombak dari kesejahteraan masyarakat. Saat ini, India memiliki tingkat kesejahteraan yang masih jauh dibawah negara-negara yang ada di Asia. Masalah yang timbul dari pendidikan yang ada di India dipengaruhi banyak faktor, dari masalah lingkungan sampai masalah internal pemerintahan. Tingkat pendapatan per kapita negara India juga masih rendah dengan sekitar 47,2\% dibandingkan pendapatan per kapita Indonesia. Pajak yang harus dibayarkan rakyat India pun lebih tinggi dibanding Indonesia sekitar 18,3\%. Selain itu tingkat kelahiran yang sangat tinggi di India memengaruhi jumlah penduduk yang melonjak tinggi. Lalu, yang cukup mencengangkan adalah tingkat kemiskinan yang ada di India sangatlah tinggi, sehingga hal tersebut mempengaruhi tingkat kesadaran masyarakat terhadap pentingnya pendidikan bagi masa depan. Remaja yang ada di India memiliki kebiasaan berpikir yang masih belum mencerminkan bangsa yang ingin berkembang, karena di India masih banyak remaja yang belum sadar akan pentingnya pendidikan. Bahwa dengan pendidikan seseorang akan mampu mengatur kehidupannya serta memberikan kontribusi yang cukup signifikan bagi peningkatan kualitas negara India di mata dunia (Tanaka 2018).

Latar belakang sebagai negara bekas jajahan Inggris seharusnya mampu membuat India memiliki tingkat pendidikan yang tinggi. Kesejahteraan masyarakatnya seharusnya juga bisa meningkat cepat layaknya negara- 
negara di Asia yang sama-sama merupakan bekas jajahan Inggris, namun hal tersebut tidak terjadi di India. Ketimpangan kualitas Sumber Daya Manusia (SDM) rakyat India sungguh sangat terlihat jelas, terutama di daerah perkotaan dan pinggiran India. Masyarakat yang tinggal di area perkotaan memiliki tingkat kualitas SDM yang baik dan menjadi daerah penyumbang terbesar dari pendapatan per kapita India. Namun, di daerah yang dibilang terbelakang di pinggiran kota besar atau bahkan di daerah pelosok India masih sangat jauh dari kata sejahtera. Sejarah India yang sebenarnya memiliki budaya yang sangat beragam mungkin bisa menjadi faktor dimana India masih belum bisa berkembang pesat karena hukum budaya atau kebiasaan yang masih tertanam. Sebagian besar perempuan di India belum mendapat kesejahteraan dalam aspek pendidikan. Hal tersebut yang kini masih terus diperjuangkan oleh tokoh-tokoh masyarakat ataupun tokoh-tokoh perempuan di India. Tidak adanya kebebasan dalam mengenyam pendidikan di India merupakan contoh dari tidak adanya kesetaraan gender di India (Tanaka 2018).

Sejarah India yang dipengaruhi oleh datangnya Inggris pula yang menjadikan ketimpangan sosial serta ketimpangan pendidikan terjadi di India. Pada era kolonialisme Inggris di India, Inggris memiliki sistem pendidikan yang tidak merata dimana pendidikan hanya diperuntukan untuk masyarakat kalangan atas saja dan menghiraukan rakyat yang berada di bawah. Hal tersebut menjadikan masyarakat India yang memiliki tingkat ekonomi rendah menjadi tidak terpantau atau tidak diberikan pendidikan yang baik. Perempuan India yang berada di kasta bawah selalu menjadi pihak yang sangat dirugikan atas fenomena tersebut. Selain keadaan ekonomi, perempuan India juga terbentur dengan kebiasaan yang mengharuskan perempuan hanya cukup mengurus rumah dan keluarga. Keadaan di masa lalu itu kemudian berpengaruh di era sekarang yang seharusnya permasalahan tersebut sudah bisa teratasi namun akibat kebiasaan yang sudah mengakar membuat hal tersebut susah untuk teratasi. Pemerintah India sebenarnya telah membuat kebijakan mengenai pendidikan namun masih banyak masyarakat masih belum sadar akan pentingnya hal tersebut (Tanaka 2018).

Seperti apa yang kita bisa lihat sekarang, ketimpangan pendidikan di India sangatlah mencolok. Baik ketimpangan dari sisi lokasi, maupun ketimpangan gender. Perempuan India yang mungkin memiliki potensi dalam aspek akademis susah untuk berkembang dikarenakan mobilitas yang sulit. Kemiskinan yang sudah terjadi dari era kolonialisme menjadi bentang tinggi yang sulit untuk di lompati. Perempuan India yang berada jauh dari ibu kota India sangat kesulitan untuk dapat mengenyam bangku 
sekolah, apalagi merasakan pembelajaran di tingkat universitas. Kemiskinan dan pendidikan sangat berkaitan satu sama lain di India. Tingkat kemiskinan dipengaruhi oleh kecerdasan masyarakat, begitu pula tingkat pendidikan yang bagus banyak dipengaruhi oleh seberapa besar tingkat kemiskinan yang ada. Di India, sekarang banyak perempuan yang berpikiran bahwa pendidikan tidak memiliki dampak yang signifikan dibandingkan jika mereka bekerja. Mereka merasa bahwa dengan bekerja mereka dapat langsung merasakan dampak dari hasil kerjanya. Namun, jika menempuh jalur pendidikan maka mereka akan merasa tidak mendapat manfaat dari esensi pendidikan tersebut (Faiz 2007).

Sesungguhnya, India memiliki universitas-universitas yang dapat dikatakan layak namun masyarakat India harus melewati dan menghadapi banyak pemenuhan pendidikan dasar terlebih dahulu. Inilah yang kemudian menjadi hambatan terbesar masyarakat India yang memiliki tingkat kualitas individu yang baik. Tujuan utama dari India pada aspek pendidikan adalah menanggulangi dan mengatasi tingkat buta huruf yang sangat tinggi dan juga pendidikan untuk perempuan. Tujuan kesetaraan gender menjadi salah satu isu utama dalam ranah pendidikan yang harus tercapai. Hal ini dapat diraih dengan menyadarkan masyarakat tentang pendidikan, khususnya masyarakat di daerah terpencil India. Sebenarnya, India mengadopsi sistem pendidikan dari negara-negara Eropa, khususnya Inggris, namun hal tersebut masih belum bisa menyadarkan masyarakat tentang pentingnya pendidikan. Pendidikan jurusan, baik di bidang teknik maupun ekonomi bisnis, menetapkan pola pendidikan yang dinamakan pendidikan Ghandi yang bertujuan untuk membentuk karakter manusia yang berkepribadian utuh, produktif, dan kreatif. Dengan sistem ini, pendidikan di India mulai meningkat, khususnya pada tahun 1950-1990-an. Kemajuan minat siswa pada sekolah kejuruan masih sangat minim atau mencapai angka 6\%, namun pada sekitar tahun 1995 terjadi pelonjakan hingga 25\% dari keseluruhan siswa di India (Tanaka 2018).

Dengan terus memperbaiki sistem dan juga memperbanyak sosialisasi tentang pendidikan di India, setidaknya dapat meningkatkan kualitas SDM di India dan dapat menanggulangi isu kesetaraan gender yang terjadi di India. Pendidikan sangat mempengaruhi kualitas negara, terutama aspek ekonomi. India dapat meningkatkan sistem ekonominya, apabila sistem pendidikan dan kemauan masyarakat terhadap pendidikan dapat meningkat. Pendidikan memberikan dampak positif bagi negara juga bagi kesejahteraan masyarakat. 


\section{Peran Berbagai Pihak dalam Mewujudkan Kesetaraan Gender di India}

Convention on Elimination of All Forms of Discrimination Against Women (CEDAW) merupakan sebuah kesepakatan hak asasi internasional yang secara khusus mengatur hak kaum perempuan. Konvensi ini mendefinisikan prinsip tentang hak-hak manusia, normanorma, dan sebuah standar kelakuan serta kewajiban yang negara peserta konvensi harus penuhi. Konvensi CEDAW juga bertindak mengenai penghapusan segala bentuk diskriminasi terhadap perempuan. CEDAW juga memungkinkan setiap individu atau kelompok yang merasa tidak puas atas pelaksanaan CEDAW di negaranya untuk mengajukan langsung permasalahannya kepada pemerintah sampai PBB. Konvensi ini juga menyatakan bahwa diskriminasi terhadap perempuan tidak hanya terjadi pada situasi yang normal tetapi juga terjadi pada saat situasi khusus, seperti kemiskinan. Pada situasi kemiskinan, diskriminasi terhadap kaum perempuan menyebabkan perempuan menduduki posisi yang paling kurang memiliki akses terhadap masalah pangan, kesehatan, pendidikan, pelatihan, dan kesempatan dalam lapangan pekerjaan atau kebutuhan lainnya (Harper 2009).

Karena itu, masyarakat internasional melalui persetujuan konvensi ini meyakini bahwa dengan dibentuknya tatanan ekonomi internasional baru berdasarkan persamaan dan keadilan akan memberikan sumbangan yang berarti pada meningkatnya persamaan antara laki-laki dan perempuan. Ditambah dengan penghapusan apartheid, segala bentuk rasisme, diskriminasi rasial, kolonialisme, neokolonialisme, agresi, pendudukan dan dominasi serta campur tangan asing pada masalah dalam negeri negara sangat penting bagi hak perempuan dan laki-laki. Usaha untuk mencapai persamaan derajat untuk kaum perempuan menjadi sangat penting mengingat sumbangan besar perempuan dalam kesejahteraan keluarga, pembangunan masyarakat, yang seringkali tidak diakui khususnya dalam hal peran reproduksi biologis ataupun sosialnya. Persamaan ini tidak akan tercapai jika tidak adanya perubahan peran tradisional antara perempuan dan laki-laki. Maka dari itu perlu dilakukan perubahan terhadap peran tradisional tersebut (Harper 2009).

Pada saat masa perjuangan kemerdekaan, tokoh nasional India yaitu Mahatma Gandhi telah menyerukan persamaan hak bagi perempuan, bahwa tugas pertama pasca kemerdekaan India adalah untuk menyediakan konstitusi kepada masyarakat tanpa ada perbedaan atas dasar jenis kelamin. Tetapi sampai saat ini masih banyak terjadi praktekpraktek pelanggaran hak perempuan terutama karena tradisi dan budaya masyarakat India yang sudah berakar sejak lama. Sementara itu, hal yang 
masih terjadi sampai sekarang ini adalah budaya dowry yang menimbulkan efek sangat negatif terhadap kondisi kehidupan perempuan di India. Sistem dowry adalah pemberian yang dilakukan oleh pihak pengantin perempuan kepada pihak pengantin laki-laki ketika menikahkan anaknya. Dowry itu sendiri bisa berupa uang tunai, barangbarang berharga seperti perhiasan, elektronik, mebel, dan lain sebagainya tergantung permintaannya dari pihak laki-laki. Semakin tinggi status sosial dan tingkat pendidikan dari calon pengantin laki-laki, maka akan semakin tinggi pula jumlah dowry yang diminta (Dalmia dan Lawrence 2005).

Sering terjadi pula permintaan keluarga pengantin laki-laki tidak berhenti saat awal pernikahan saja, tetapi terus berlanjut sampai anak-anak mereka sudah menikah. Sehingga, pihak pengantin perempuan diharuskan memberikan apa yang diminta oleh pihak keluarga laki-laki jika ingin anak mereka diperlakukan dengan baik oleh keluarga pihak laki-laki. Budaya dowry telah menyebar hampir ke seluruh lapisan masyarakat India, pada empat abad yang lalu sistem dowry hanya terjadi di kalangan tertentu umat Hindu yaitu pada kalangan kasta kelas atas. Namun, saat ini tradisi dowry telah menyebar ke dalam kalangan kelas menengah dan bawah masyarakat Hindu, Kristen, dan kaum Muslim di India. Di bagian India Utara, masyarakat Muslim mulai mempraktekan dowry sejak puluhan tahun belakangan. Dowry ini dianggap sebagai kompensasi, dikarenakan anak perempuan tidak mendapatkan hak waris seperti anak laki-laki. Karena adanya sistem dowry inilah anak perempuan dianggap sebagai 'beban' bagi keluarganya, karena anak perempuan dianggap akan membebani keluarganya secara finansial di kemudian hari (Dalmia dan Lawrence 2005).

Pemerintah India sudah mengambil langkah-langkah untuk mengatasi hal ini dengan mengeluarkan Dowry Prohibition Act pada 1 Juli 1961. Berdasarkan undang-undang ini, siapapun yang memberi atau menerima dowry bisa dijatuhi hukuman penjara lima tahun dan juga denda Rs 15,000 atau sejumlah nilai dowry yang diberikan jika nilai dowry itu lebih dari denda yang ditentukan. Berbagai pihak yang membantu proses dowry ini juga akan dijatuhi hukuman. Namun, undang-undang yang dikeluarkan oleh pemerintah ini rupanya tidak dapat mencegah adanya praktek dowry di kalangan masyarakat karena masih terdapat kasuskasus pembunuhan atau pembakaran perempuan berkaitan karena masalah dowry ini. Pada tahun 70-an dan 80-an, para aktivis perempuan melakukan sebuah demonstrasi dan unjuk rasa menentang praktek dowry dan kematian yang diakibatkan oleh sistem dowry. Banyak yang melakukan protes di jalan-jalan dan sebagian dari para aktivis secara 
secara spontan mengkonfrontasikan pelaku secara langsung untuk mempermalukan para pelaku di komunitasnya. Mereka juga berunjuk rasa di depan kantor-kantor polisi setempat untuk memprotes lambatnya reaksi dari para penegak hukum dalam menangani kasus ini. Usaha yang dilakukan para aktivis ini berhasil namun hanya untuk jangka pendek. Pemerintah memang mengeluarkan peraturan tambahan atau amandemen terhadap undang-undang mengenai dowry namun praktek penegakkan hukum dan pelaksanaannya belum maksimal (Dalmia dan Lawrence 2005).

Rendahnya status perempuan di masyarakat India dan anggapan masyarakat bahwa anak perempuan hanya akan menjadi beban bagi keluarganya membuat banyak orang tua melakukan aborsi atau pembunuhan terhadap bayi perempuan. Jika bayi tersebut dibiarkan hidup mereka akan ditelantarkan oleh keluarganya. Lantas, yang menjadi perhatian saat ini adalah berbagai macam kasus pembunuhan bayi perempuan di India dan aborsi selektif terhadap calon bayi berjenis kelamin perempuan. Berdasarkan hasil studi mengenai pembunuhan bayi-bayi perempuan di India, tradisi ini telah berlangsung lama dan sudah dianggap sebagai hal yang wajar untuk menghindari memiliki anak perempuan. Jumlah perempuan yang semakin menurun inilah yang mengakibatkan semakin terpuruknya posisi perempuan di India. Di daerah Baghpat, India terdapat adanya praktek berbagi istri yaitu seorang perempuan yang sudah menikah dengan seorang laki-laki harus mengalami penderitaan dengan menjadi istri dari saudara-saudara lelaki dari suaminya (Dalmia dan Lawrence 2005).

Anak perempuan tersebut akan mengalami tindak kekerasan dan penyiksaan jika menolak perintah dari anggota keluarga laki-laki yang ada. Akibat dari tradisi dowry yang membuat stigma memiliki anak perempuan adalah beban bagi keluarga dan terpuruknya derajat seorang perempuan di India, maka ramai masyarakat India yang melakukan operasi jenis kelamin terhadap anak perempuannya yang berumur di bawah 14 tahun. Anak-anak ini dirubah jenis kelaminnya oleh para orang tua agar kelak mereka tidak perlu memberikan dowry. Tren operasi jenis kelamin ini dikenal sebagai genitoplasty. Para orang tua kaya yang berasal dari kota Delhi dan Mumbai berbondong-bondong melakukan operasi jenis kelamin dengan biaya sekitar 2.00o poundsterling atau sekitar 27,6 juta rupiah untuk mengganti kelamin anak perempuan mereka (Dalmia dan Lawrence 2005).

Sejak masa kemerdekaan India, sejumlah undang-undang telah ditetapkan dengan tujuan memberikan perlindungan bagi kaum perempuan. Beberapa contohnya yaitu Dowry Prohibition Act, Equal 
Remuneration Act pada tahun 1986, The Hindu Marriage Act pada tahun 1956, The Hindu Succession Act pada tahun 1956, The Islamic Women tahun pada tahun 1986, The Commission of Sati Act pada tahun 1987, Protection of Women from Domestic Violence Act pada tahun 2005, dan lain sebagainya. Undang-undang yang bertujuan untuk melindungi kaum perempuan itu banyak yang telah dikeluarkan oleh pemerintah India jauh sebelum pemerintah India meratifikasi CEDAW. Namun, penegakan hukum di lapangannya masih sangat kurang. Mahkamah Agung India dalam putusan 21 Agustus 2006 mengatakan bahwa untuk memberantas kejahatan sosial dari tradisi dowry, langkah-langkah yang efektif harus diambil dari masyarakat itu sendiri. Harus diadakan kampanye nasional yang kuat untuk menciptakan kesadaran sosial tentang penghapusan sistem dowry. Akibat dari sistem dowry itu juga yang mengakibatkan menurunnya jumlah bayi perempuan yang lahir. Sehingga, pemerintah India mengeluarkan larangan bagi rumah sakit di India untuk memberitahukan jenis kelamin bayi kepada orang tua untuk mencegah aborsi selektif walau kenyataannya hal itu akan bocor juga. Pemerintah India juga melakukan banyak upaya untuk mengatasi hal tersebut, di antaranya adalah pemberian makan gratis, jaminan biaya pendidikan, bahkan hadiah uang untuk keluarga yang merawat anak perempuannya agar tingkat pembunuhan bayi perempuan atau aborsi selektif ini dapat berkurang ataupun berhenti. 


\section{Kesimpulan}

Kesetaraan gender di India masih sangat jauh dari kata tercapai. Di India sendiri yang masih harus mendapat perhatian adalah bagaimana mengurangi angka ketidakadilan pada perempuan dan bagaimana menghapuskan kekerasan pada perempuan. Adanya tradisi-tradisi budaya di India yang telah mengikat sejak berabad-abad lalu menjadi tantangan yang harus dihadapi. India dengan masyarakatnya yang masih kental dengan budayanya menjadi alasan sulitnya mewujudkan kesetaraan gender di India ini. Karena banyak dari tradisi budaya tersebut yang merugikan perempuan, seperti budaya dowry yang mengakibatkan banyaknya bayi perempuan dibunuh dan dianggap tradisi yang wajar. Solusi yang ditawarkan dari artikel ini ialah, perlunya peningkatan pendidikan khususnya dikalangan remaja. Remaja dimana kondisi pemikirannya masih bisa dibentuk diharapkan akan terbentuk pemikiran baru tentang pentingnya kesetaraan gender melalui pendidikan yang diberikan dan bisa menghapus tradisi budaya yang dilakukan oleh orang tuanya. Cara ini dianggap bisa menjadi pemutus rantai budaya yang merugikan perempuan. Dengan terbentuknya pemikiran baru di kalangan remaja ini, diharapkan bahwa di masa depan tradisi ini bisa dihapuskan dan India bisa menjadi salah satu negara yang berhasil mencapai kesetaraan gender. 


\section{Daftar Pustaka}

\section{Buku}

Harper, E. 2009. International Law and Standars Applicable in Natural Disaster Situation. Italia: International Development Law Organization, pp. 122-123.

\section{Artikel Jurnal}

Dalmia, S. dan Lawrence, P. G. 2005. "The Institution of Dowry in India: Why It Continues to Prevail", The Journal of Developing Areas, 38 (2): 71-93.

Tanaka, A. 2018. "Sistem Among, Dalton, dan Shanti Niketan Kajian Komparatif Historikal Sistem Pendidikan Indonesia, Amerika, dan India serta Implikasinya bagi Kemajuan Pendidikan di Indonesia Konteks Kekinan”, Jurnal Teknologi Pendidikan Madrasah, 1 (1): 5373 .

\section{Artikel Daring}

Alinea.id, 2019. "Bank Dunia: Hanya 6 negara yang memiliki kesetaraan gender sempurna", [Daring] Alinea.id. Tersedia dalam [https://www. alinea.id/dunia/bank-dunia-6-negara-memiliki-kesetaraan-gender-sempurna-b1XcBghY1] (Diakses [16 Mei 2019]).

Apriani, P., 2015. 'Kekerasan Seksual di India: Relasi Kuasa Kasta dan Gender", [Daring] The Global Review. Tersedia dalam [https://theglobal-review.com/kekerasan-seksual-di-india-relasi-kuasa-kasta-dan-gender/] (Diakses [16 Mei 2019]).

BBC, 2018. "Is India really the most dangerous country for women?", [Daring] BBC News. Tersedia dalam [https://www.bbc.com/news/ world-asia-india-42436817] (Diakses [16 Mei 2019]).

Faiz, P. M., 2007. "Peran Hukum dalam Mengawal Pendidikan di India”, [Daring]. Tersedia dalam [https://panmohamadfaiz. com/2007/08/29/hukum-dan-pendidikan-di-india/] (Diakses [16 Mei 2019]).

Komisi Perlindungan Anak Indonesia, 2017. "Mencapai Kesetaraan Gender dan Memberdayakan Kaum Perempuan”, [Daring] Kemenpppa.

Tersedia dalam [https://www.kemenpppa.go.id/index.php/page/ read/31/1439/mencapai-] (Diakses [16 Mei 2019]). 


$\begin{array}{lllll}\text { Mencapai Kesetaraan Gender", } & \text { [Daring] } & \text { Kemenpppa. } \\ \text { Tersedia } & \text { dalam } & \text { [https://www.kemenpppa.go.id/index.php/ } \\ \text { page/read/31/1436/hak-perempuan-] } & \text { (Diakses } & \text { [16 } & \text { Mei 2019]). }\end{array}$

Kania, D., 2017. "5 Kasus Pernikahan Dini di Indonesia yang Jadi Viral”, [Daring] OkeLifeStyle. Tersedia dalam [https://lifestyle.okezone. com/read/2017/12/01/196/1823883/5-kasus-pernikahan-] (Diakses [16 Mei 2019]).

Purnama, R. R., 2019. "Babak Belur Dipukuli Suami, Ratna Lapor Polisi Naik Mobil Bak Terbuka”, [Daring] SindoNews. Tersedia dalam [https://metro.sindonews.com/read/1382582/170/babak-belur-dipukuli-suami-] (Diakses [16 Mei 2019]).

Wuryasti, F., 2016. "UU Perkawinan Mesdiskriminasi Perempuan", [Daring] Media Indonesia. Tersedia dalam [https://mediaindonesia. com/read/detail/32638-uu-perkawinan-mendiskriminasi-] (Diakses [16 Mei 2019]).

Wirawan, U., 2019. "Demi Kesetaraan Gender, Tiga Juta Wanita India Berdemo", [Daring] Berita Satu. Tersedia dalam [https://www.beritasatu.com/dunia/530840/demi-kesetaraan-gender-tiga-juta-perempuan-india-berdemo] (Diakses [16 Mei 2019]). 